\title{
Administrative Perspective on Violence in School Environment in Official High Schools (Sample of Bursa Province)
}

\author{
Halime Güngör ${ }^{1}$, Muammer Değirmendere², Suat Gürbüz ${ }^{3}$
}

Article History:

Received 02.05.2021

Received in revised

form 27.11.2021

Accepted

Available online

01.03.2022

\begin{abstract}
The aim of this study is to determine the views of school managers about the situation, time, place, the groups that violence incidents experienced and causes of violence in the level of students, teachers, administrators and parents in official high schools in Bursa. Phenomenological design, one of the qualitative research methods, was used in the study. The study group consists of 54 public high school managers in January-March 2020. A semi-structured interview form developed by the researchers was used as a data collection tool in the study. Face-to-face interviews were conducted with 54 high school managers, including 39 school principals, 14 assistant principals and 1 senior assistant principal. The data were analyzed with categorical content analysis and frequency analysis, which are among the types of content analysis. Findings show that violence is experienced more intensely in Vocational and Technical high schools because students experience uncertainty about setting goals for the future. Violence is experienced more intensely in Sports High Schools may be due to the fact that students participate more in physical activities, have more physical strength and have difficulty controlling their physical power when they get angry because they have difficulty in anger management as of their age.
\end{abstract}

(C) IJERE. All rights reserved

Keywords: Violence, high school, principals, teachers, students, parents

\section{INTRODUCTION}

Violence is a phenomenon that can occur to every living unit all over the world, has multidimensional harms and can be encountered in various ways. Individuals or groups of all ages can be exposed to violent behavior at anytime and anywhere during their lives. The ability to control aggression that is one of the basic motives of human nature, and the ability to respect the fundamental rights and freedoms of living beings are learned through social learning and adaptation to social life and the basis of these are family, environment and school. Considering the phenomenon of violence on the basis of culture, beating and being beaten have caught many of us at school, at home or on the street, as it has been perceived as normal behavior for centuries, especially in Turkey (Şener, 2019).

According to Özdere and Terzi (2018), violence is all malicious and deliberate behaviors such as humiliation, injury, harm, deprivation, and isolation that carried out with the help of physical, psychological, social, sexual, economic, cyber or signs that threaten the life, freedom, will, rights, health and well-being of individuals or prevent their development. According to Taşar (2019) violence is the events that decelerate the mental, moral and physical development of the individual or cause physical and psychological traumas, prevent the person from participating in social life and according to Yüzer (2013), violence is a tool of attack, pressure and force on physical or mental integrity.

When the literature is examined, the reasons that leaden young people to commit violence can be listed as follow: having difficulty in controlling their behavior, low tolerance to disappointment, not knowing how to cope with when faced a frustration, poor social skills such as problem solving, anger management and effective communication, neglect of children's educational life, inconsistent and very harsh disciplinary practices of parents, violence and abuse at home, substance use and symptoms of depression in children (Çakır, 2019), school structure, sociocultural conditions in schools and social networks within the school (Ünlü et al. 2013), low expectations about school (Arslan, 2015). According to EARGED (2008), the reasons that reveal the phenomenon of violence are as follow; prenatal problems and birth trauma can be caused brain damage may cause these people to be exposed to violence and tend to violent behavior throughout their life. The fact that the child is an unwanted child in terms of gender, number and timing increases the violent behaviors towards the child and may lead to the development of the child's personality in a way that exhibits violent behaviors. The person's self-evaluation of his/her mental health as bad may cause exposure to violent behavior. 
Hyperactivity/impulsivity, depression, low self-perception, anxiety states often coexist with violent behavior. Mental health problems may cause the child to be involved in violent incidents. School failure and absenteeism cause children and young people to be exposed to violence and to have violent behaviors more.

Erçetin (2006) explains the causes of violence as prenatal and birth-related factors, hyperactivity, lack of parent's supervision, discipline and negative parents' attitudes, broken families, parental guilt, la rge families, socio-economic deprivation, peer effects, school effects, low intelligence, low school achievement, high school absenteeism. According to the findings of study conducted by Hoşgörür and Orhan (2017), the main causes of violence in schools are listed as environmental, familial, and individual factors. Gemici (2008) listed causes of violence as individual, peer group and familial factors, and Ögel, Tarı and Yılmazçetin Eke (2006) listed them as environmental, social, familial and individual factors.

Although violence is seen as a crime against humanity and violation of human rights as a behavior and method, the fact that it continues to increase in every period and that the practitioners descend until the age of children make it obligatory to work on it and take precautions (Çakır, 2019). It should not ignored that the violence experienced in schools negatively affects the quality of life, success and future perspectives of the young people, and that school is the last opportunity to change or minimize the tendencies and behaviors towards violence (Özgür, Yörükoğlu and Baysan Arabac1, 2011). Prevention of violence in schools and the formation of safe schools is a planned teamwork that should be shared by the ministry, national education directorates, police units, the school administration, teachers and all school personnel, including family, media and tradesmen around the school, in short, all segments of the society (Avcl, 2010).

Arslan (2015) conducted a quantitative study in Batman in order to determine in which time period, in which environments, under what reasons and conditions the violence occurred. In the study, it was concluded that there was an increase in verbal, physical and emotional violence types among students, and behaviors such as stealing, damaging school items, smoking, using drugs, and fighting with sharp objects became more common. A quantitative research was conducted by Çubukçu and Dönmez (2012) in order to reveal the views of primary school principals about the types of violence and to determine the methods they use to cope with violence. In the study, it was found that verbal violence was the most common type of violence among students, and there was a significant difference in favor of female principals in terms of physical violence, and assistant principals in terms of sexual violence. Furthermore, a qualitative study was conducted by Atmaca and Öntaş (2014) in order to determine the types of violence that teachers are exposed through parents, violence types and violence reflections on teachers' daily school activities. According to the results of the study, it was observed that parents' violence against teachers differ physically and psychologically depending on social and economic conditions, teachers sometimes shared this with the school administration and other teachers in order to cope with negative effects of the violence and also some teachers received medical help to eliminate the effects of violence.

A quantitative research was conducted by EARGED (2008) in order to determine how primary and secondary school students perceive the concept of violence and what the factors that leads them to violence are. The results obtained in the research are as follows; students do not perceive the concept of violence in the literary sense, they experience verbal violence more than other types of violence, media, circle of friends and the environment play a role in spreading violence, one of every four students is generally subjected to violence in their lives, most of all were violent by their friends, they used violence because of the feeling of proving themselves, because of the competitive environment among themselves, they generally prefer to remain silence in adversities experienced, they do not intend to respond to violence with violence, failure is an important phenomenon that makes people prone to violence.

Özgür, Yörükoğlu and Baysan Arabacı (2011) conducted a research in order to determine high school students' situations of encountering and perceiving violence, their level of violence tendency and the factors affecting this. The results obtained in the research are as follows; $10.3 \%$ of the students were exposed to violence, $51.4 \%$ of these students were exposed to violence by their friends and at school, the type of violence that students are mostly exposed is physical violence, students' gender, class level, family's income level and father's working status are effective in violent tendency, male students and students whose fathers are not working have higher tendency to violence. 
A research was conducted by Tatlllığlu (2016) to determine the views of teachers, administrators and students about the sources of violence in secondary schools. The results of this research are as follows; it was found that the majority of the students were under the influence of TV series, they were affected by the negative words of the teachers, they played violent games in computer games, they could not control their anger, parents did not cooperate enough with the school, the use of harmful substances in the environment was common, domestic communication was insufficient, and their academic success was low.

Studies conducted abroad on the causes of violence also show similar results. According to results of the research study conducted by Mehinezhad and Rashki (2018) on the causes of violence of students from the teachers and administrators' perspective; all external factors such as family, media, personal characteristics, society, and victimization and internal factors such as the characteristics of teachers, school management and school structure have an influential role in the incidence of violence of students. Also results show that the principal is more effective than other factors in violence phenomenon. In addition, results of the another research study conducted by Ncontsa and Shumba (2013) on the nature, causes and effects of school violence in four South African high schools showed that bullying, vandalism, gangsterism, indiscipline, intolerance, and corporal punishment were prevalent in schools. Furthermore, results show that school violence affects learners on the loss of concentration, poor academic performance, bunking of classes and depression. Furthermore, Opere, Kamere and Wawire (2019) found that school violence occurs in the form of verbal abuses, physical fights, bullying and arson attacks on their research study. In addition, they found that violence also emerged that violence occurred during meals, social events and on the way going home from school and that the main perpetrators included classmates, prefects and even teachers. According to the results of the study conducted by Von Reininghaus, Castro and Frisancho (2013) showed that the main cause of violence is social influences such as socialization processes at home, family values, quality of education, and influence of mass media.

The issue of taking precautions against violence in the school environment is still on the agenda and is among the issues that are emphasized. The violence perpetrated by students can take different forms such as insulting the school counselor, verbally threatening the school principal by causing physical harm, dropping another student by pushing the school corridor, fighting with the school bus driver, or injuring and killing a teacher with a gun or knife (Sezgin and Özok, 2006). It is one of the most important duties of the school and therefore the school administrators to protect the students against violence, aggression, alcohol, drugs, sexual harassmentcaused by the students in the school or the environment, and to ensure the highest level of safety against the crisis situations caused by traffic, fire, flood, earthquake (Sayın, 2008). Although it is a case that students exhibit violent behaviors in schools, violence incidents experienced at the level of parents, teachers and administrators continue to be on the agenda both in Turkey and in different countries of the world. The phenomenon of violence should be discussed in every aspect by researchers, educators, parents, students, lawyers, media and individuals from all professions.

As a matter of fact, "the access and acquisitions of the concepts such as secure internet, cyber security, cyber bullying and data security, which have been transformed into primary school courses, will be monitored and necessary improvements will be made through monitoring and evaluation studies" is targeted in Goal 2-1 in the "Digital Content and Skill Supported Transformation in Learning Processes" part of the 2023 Vision Document. In this sense, monitoring the violent incidents experienced in the high schools environment in Bursa by administrative point of view and evaluate the current situation will contribute to the current precautions that can be taken to provide students in Bursa with a more qualified and safe education environment.

As demonstrated by the researches, prevention of violence in schools is important in terms of creating a safe education environment. In this study; it is aimed to determine the views of school managers about the situation, time, place, groups that violence incidents experienced and causes of violence experienced at the level of students, teachers, administrators and parents in public high schools in Bursa.

The main question of the study is as follows: What are the views of school managers about the situation, time, place, groups that violence incidents experienced and causes of violence at the level of students, teachers, school managers and parents in public high schools in Bursa? Do the views of school managers differ according to the type of high school? Sub questions are as follow; 
What are the views of the school managers regarding the violence incidents in the school environment? Do these views differ according to the type of high school?

According to the views of the school managers, where are individuals exposed to violence in the school environment?

According to the views of the school managers; in what time period are individuals exposed to violence in the school environment?

In which groups (student / teacher / school manager / parent) are the violent incidents experienced?

What are the causes of violence in the school environment?

\section{RESEARCH DESIGN AND METHOD}

Phenomenological design which is one of the qualitative research methods was used in this study. Qualitative research is a type of research in which qualitative data collection techniques such as observation, interview and document analysis are used, and the process of revealing perceptions and events in a realistic and holistic manner in the natural environment is followed (Yıldırım \& Şimşek, 2008). Phenomenology, one of the qualitative research methods, is a method that focuses on evaluating lived experience (Jasper, 1994; Miller, 2003).

\section{Study Group}

The population of the research consists of 228 official high schools in Bursa, according to the data of MEBBiS database secondary education institutions 2019-2020. Special education high schools were not included in the study. While determining the participants, two criteria were taken into consideration: the number of schools in the districts and the number of disciplinary punishments given to students in schools. Considering the statistics of Bursa Provincial Directorate of National Education e-school Management Information System on disciplinary penalties given to students, schools with the least disciplinary punishment and the most disciplinary punishment were selected in order to ensure internal consistency. Volunteering for school administrators who will participate in the study was based. 54 school managers were reached in this study.

\section{Data Collection Tools}

A semi-structured interview form developed by the researchers was used as a data collection tool in the study. In the preparation phase of the semi-structured interview form, firstly the literature was examined, secondly the form prepared by the researchers in line with the aim of the study and literature, then the views of 2 field experts were taken, the necessary changes were made and the final form was given. Lastly, 3 high school managers were interviewed on a voluntary basis.

The necessary research permission was obtained from Bursa Provincial Directorate of National Education in December 2019, it was planned to collect all of the data through face-to-face interviews, and the process of collecting data was completed in March 2020 with 54 school managers, 39 school principals, 14 assistant principals and 1 senior assistant principal, in line with the implementation plan.

\section{Data Analysis}

The data were analyzed by categorical content analysis and frequency analysis, which are among the types of content analysis. In content analysis, firstly, data is converted into units that can be analyzed (Mayring, 2000). In the categorical content analysis process, based on the literature of the study and the interview questions, firstly, the codes in the interview texts were conceptualized and codes were created. The coding was made by two experts separately for the reliability of the study, and the coding made afterwards were checked. During the coding process, the responses of the participants were numbered and the codes were frequencyd, so that the qualitative data were digitized. After the codes were created, sub-themes were determined, and finally themes were created by combining the sub-themes. Naming and definitions have been made for the theme and sub-themes. While presenting the findings, direct quotations from the views of the 
participants were included in order to reflect the accuracy of the findings and ensure the validity of the study. The frequency (f) and percentage (\%) values were calculated for the demographic characteristics of the participants forming the study group. The demographic characteristics of the participants participating in the study are presented in Table 1.

Table 1: Demographic characteristics of participants

\begin{tabular}{llcccc}
\hline \multicolumn{1}{c}{ School Type } & Frequency & Percent & $\begin{array}{l}\text { Valid } \\
\text { Percent }\end{array}$ & $\begin{array}{c}\text { Cumulative } \\
\text { Percent }\end{array}$ \\
\hline $\begin{array}{l}\text { Vocational and Technical Anatolian } \\
\text { School }\end{array}$ & High & 25 & 46.30 & 46.30 & 96.30 \\
Anatolian High School & & & & \\
Anatolian Imam Hatip High School & 14 & 25.92 & 25.92 & 35.18 \\
Science High School & 5 & 9.26 & 9.26 & 9.26 \\
Multi Program High School & 5 & 9.26 & 9.26 & 50.00 \\
Sports High School & 3 & 5.56 & 5.56 & 40.74 \\
Total & 2 & 3.70 & 3.70 & 100 \\
\hline
\end{tabular}

\begin{tabular}{lllll}
\hline \multicolumn{1}{c}{ Gender } & & & & \\
\hline Male & 46 & 85.18 & 85.18 & 85.18 \\
Female & 8 & 14.82 & 14.82 & 100 \\
Total & 54 & 100 & 100 & \\
\hline
\end{tabular}

\begin{tabular}{lllll}
\hline \multicolumn{1}{c}{ Position } & & & & \\
\hline Principal & 39 & 72.22 & 72.22 & 72.22 \\
Assistant Principal & 14 & 25.93 & 25.93 & 100 \\
Senior Assistant Principal & 1 & 1.85 & 1.85 & 74.07 \\
Total & 54 & 100 & 100 & \\
\hline \multicolumn{1}{c}{ Education Level } & & & & \\
\hline Undergraduate & 41 & 75.93 & 75.93 & 75.93 \\
Master Degree-Other & 7 & 12.96 & 12.96 & 88.89 \\
Master Degree - Educational Administration & 6 & 11.11 & 11.11 & 100 \\
Total & 54 & 100 & 100 & \\
\hline
\end{tabular}

\begin{tabular}{lllll}
\hline \multicolumn{1}{c}{ Management Seniority } & & & & \\
\hline $\mathbf{1 - 4}$ year & 10 & 18.52 & 18.52 & 18.52 \\
$\mathbf{5 - 8}$ year & 10 & 18.52 & 18.52 & 37.04 \\
$\mathbf{9 - 1 2}$ year & 10 & 18.52 & 18.52 & 55.56 \\
$\mathbf{1 3 - 1 6}$ year & 10 & 18.52 & 18.52 & 74.08 \\
$\mathbf{1 7 - 2 0}$ year & 8 & 14.80 & 14.80 & 88.88 \\
$\mathbf{2 1 - 2 4}$ year & 3 & 5.56 & 5.56 & 94.44 \\
$\mathbf{2 5 - 2 8}$ year & 3 & 5.56 & 5.56 & 100 \\
Total & 54 & 100 & 100 & \\
\hline
\end{tabular}

As seen in Table 1, 3.70\% of the participants have been working in Sports High Schools, $5.56 \%$ in a Multi-Program High School, 9.26\% in a Science High School, 11.11\% in an Anatolian Imam Hatip High School, 24.07\% in an Anatolian High School, and $46.30 \%$ in a Vocational and Technical Anatolian High School. 
$85.18 \%$ of the participants are men, $14.82 \%$ are women, $72.22 \%$ are principals, $1.85 \%$ is senior assistant principals, $25.93 \%$ are assistant principals. $75.93 \%$ of the participants are undergraduate, $11.11 \%$ have master degree in educational administration, $12.96 \%$ have master degree in other fields and there is no participant who has completed his doctorate. $18.52 \%$ of the participants have management seniority of $1-4,5-8,9-12,13-$ 16 years, $14.80 \%$ for $17-20$ years, and $5.56 \%$ for $21-24,25-28$ years.

\section{FINDINGS}

As a result of the analysis of the obtained data, a total of 3 themes have been revealed. These themes are; the overview of violence in schools; time, place and groups in violence incidents in schools, and the causes of violence in the school environment. There are sub-themes under the themes.

Theme 1. Findings on Overview of Violence in Schools

Findings on overview of violence in schools are presented in Table 2.

Table 2: Theme 1. Overview of violence in schools

\begin{tabular}{llll}
\hline \multicolumn{1}{c}{ School Type } & \multicolumn{2}{c}{ Codes } \\
\cline { 2 - 4 } & & Yes & Total \\
\hline $\begin{array}{l}\text { Vocational and Technical Anatolian High } \\
\text { School }\end{array}$ & 25 & 0 & 25 \\
Anatolian High School & 10 & 4 & 5 \\
Anatolian Imam Hatip High School & 3 & 2 & 3 \\
Multi-Program High School & 2 & 5 \\
Science High School & 2 & 3 & 2 \\
Sports High School & 2 & 0 & 54 \\
Total & 44 & 10 & 5
\end{tabular}

As seen in Table 2, all managers from Vocational and Technical Anatolian High Schools and Sports High Schools, who participated in the study, stated that violence was experienced in their schools. One of the school managers of the Vocational and Technical Anatolian High School stated the situation as "We have very terrible violent incidents (K44)". Another Vocational and Technical Anatolian High School manager said that "There have been 3 quarrels for 2 years. This is better than most other schools. Cause here is very cosmopolitan, everyone is respectful to each other (K19)".

The extent of violent incidents varies from school to school. While 3 of the Science High School managers, 4 of Anatolian High School managers and 2 of Anatolian Imam Hatip High School managers stated that there was no violence in their schools, 10 of the Anatolian High School managers and 3 of the Anatolian Imam Hatip High School managers stated that there were violence in their schools. One of the Anatolian High School managers expressed the situation as "Every school has a culture, here is Anatolian High School. Children grown up in the same street, someone comes here; someone goes to Vocational and Technical Anatolian High School next door. Human adapts to where s/he goes. There is no violence in our school (K14)". Another Anatolian High School manager stated that violence incidents happened rarely in the school, explained the views such as "Violence happens very rarely in my school. Violence is everywhere in society (K35)".

\section{Theme 2. Findings on Time, Place and Groups in Violence Incidents in Schools}

The theme of time, place and groups in violent incidents in schools is gathered under 3 sub-themes; the places where individuals are exposed to violence in the school environment, the time period when individuals are exposed to violence in the school environment, and the groups in which violence is experienced in the school environment.

Theme 2-Sub Theme 1. Findings on the Places where Individuals are Exposed to Violence in the School Environment in Table 3.

Findings on the places where individuals are exposed to violence in the school environment are given 
Table 3: Theme 2-Sub Theme: The Places where individuals are exposed to violence in the school environment

\begin{tabular}{lcc}
\hline \multicolumn{1}{c}{ Codes } & $\mathrm{f}$ & $\%$ \\
\hline School garden & 19 & 20 \\
Classroom & 17 & 17.90 \\
School environment & 16 & 16.84 \\
Corridor & 15 & 15.79 \\
Not experienced & 7 & 7.37 \\
Internet environment & 7 & 7.37 \\
Toilets & 5 & 5.26 \\
Canteen & 4 & 4.21 \\
Everywhere & 3 & 3.16 \\
Sports areas & 3 \\
The places where there are no cameras & 1 & 1.05 \\
Total & 1 & 1.05 \\
\hline
\end{tabular}

As seen in Table 3, 7.37\% of the school managers stated that there was no violence in any part of their school. According to the views of the school managers, $20 \%$ of the violent incidents experienced in the school garden, $17.90 \%$ of them experienced in the classroom, $16.84 \%$ of them experienced in the school environment, $15.79 \%$ of them experienced in the corridor, $7.37 \%$ of them experienced in the internet, $5.26 \%$ of them experienced in the toilet, $4.21 \%$ of them experienced in canteen and $1.05 \%$ of them experienced in sports areas and places where there are no cameras. $3.16 \%$ of the administrators stated that violence can be experienced everywhere in the school environment.

When the distribution of the places where individuals are exposed to violence in school environment according to the type of school is examined; according to the views of the school managers violence is experienced in the school garden and classroom environment in the Anatolian Imam Hatip High Schools and violent incidents are experienced everywhere in Anatolian High Schools, including the corridor, the school garden, the school environment, the classroom environment, the canteen, the toilet, the sports areas, the places where there are no cameras and the internet environment. According to the views of the school managers violence is experienced in corridors, school gardens, around the school in Multi-Program High Schools; on the internet in Science High Schools; is experienced everywhere in Vocational and Technical Anatolian High School including the corridor, school garden, school environment, classroom environment, canteen, toilet, internet environment and also is experienced everywhere in Sports High Schools including school garden, school environment, classroom environment and toilet.

One of the school managers of the Vocational and Technical Anatolian High School explained views regarding the violent incidents experienced in the school environment and in ternet environment like that "There are students who pass over the turnstile in order not to use the subway card. They fight after school. They are communicating on the phone. There are restrictions on school internet, but they crack the password. The phones are collected, but there are some who do not give, even partially. They use social media and gathering to fight. (K32)". Another Vocational and Technical Anatolian High School manager expressed the opinion on violent incidents in the classroom and on the internet as "As events happen instantly, the violent incidents usually happen in their own classes. They attack each other a lot on social media. In general, male students fightmore (K36)".

Theme 2-Sub Theme 2. Findings on the Time Period when Individuals are Exposed to Violence in the School Environment

Findings on the time period when individuals are exposed to violence in the school environment are given in Table 4. 
Table 4: Theme 2-Sub Theme 2: The Time period when individuals are exposed to violence in the school environment

\begin{tabular}{lll}
\hline \multicolumn{1}{c}{ Codes } & $\mathrm{f}$ & $\%$ \\
\hline Lesson Break & 34 & 34.69 \\
After school & 21 & 21.43 \\
Idle class & 14 & 14.29 \\
Lunch Break & 9 & 9.19 \\
Not experienced & 5 & 5.10 \\
Outside of school & 5 & 5.10 \\
The beginning of the lesson until the teacher arrives & 4 & 4.08 \\
At lesson & 4 & 4.08 \\
No comment & 2 & 2.04 \\
Total & 98 & 100 \\
\hline
\end{tabular}

As seen in Table $4,5.10 \%$ of the school managers stated that there was no violence anywhere in their school, and $2.04 \%$ did not comment on this issue. According to the views of school managers, $34.69 \%$ of the violent incidents in the school environment were experienced during the lesson break, $21.43 \%$ of the incidents are experienced after school, $14.29 \%$ of them are experienced during the idle class, $9.19 \%$ of them are experienced during lunch break, $5.10 \%$ of them are experienced outside of the school, $4.08 \%$ of them are experienced during beginning of the lesson until the teacher arrives.

When the distribution of the time periods in which individuals are exposed to violence in schools according to the type of school is examined, according to the views of the school managers, it can be said that the violent incidents in the Anatolian Imam Hatip High Schools are experienced during the lesson break and lunch breaks, in the Anatolian High Schools during the lesson break, lunch break, idle class, until the beginning of the lesson until the teacher arrives, after the school and outside of school. Violent incidents are experienced during the lesson break, lunch break, until the beginning of the lesson until the teacher arrives and after the school in the Multi-Program High Schools; outside the school times in the Science High Schools; during the lesson break, lunch break, the idle class, until the beginning of the lesson until the teacher arrives, at lesson, after the school in the Vocational and Technical Anatolian High School; during lesson breaks and the idle class in Sports High Schools.

It can be said that violent incidents in schools occur mostly when the control is less. One of the school managers of Vocational and Technical Anatolian High Schools expressed the views as "Breaks. The breaks of departments and culture lessons are different; it can happen at that time (K26)". Anatolian High School manager expressed the views as "Break, lunch break generally. It happens when students are uncontrolled. (K20)". The manager of the Sports High School stated that "Any time the students are strayed is dangerous. It doesn't happen much at lunchtime. If a student has a job, a goal, an expectation, there is no problem, if not, problems occur (K27)". 
Theme 2-Sub Theme 3. Findings on the Groups in which Violence is Experienced in the School Environment

Findings on the groups in which violence is experienced in the school environment are given in Table 5.

Table 5: Theme 2-Sub Theme 3: The Groups in which violence is experienced in the school environment

\begin{tabular}{lll}
\hline \multicolumn{1}{c}{ Codes } & & $\mathrm{f}$ \\
\hline Student - Student & 49 & 43.75 \\
Student - Teacher & 23 & 20.54 \\
Parent - Administrator & 17 & 15.18 \\
Parent - Teacher & 12 & 10.71 \\
Student - Administrator & 4 & 3.57 \\
Teacher - Administrator & 4 & 3.57 \\
Not experienced & 3 & 2.68 \\
Total & 112 & 100 \\
\hline
\end{tabular}

As seen in Table 5, according to the school managers' views on the groups in which violence is experienced in schools, $43.75 \%$ of the violent incidents are experienced among students, $20.54 \%$ of them are experienced between students and teachers, $15.18 \%$ of them are experienced between parents and school managers, $10.71 \%$ of them are experienced between parents and teachers, $\% 3.57$ of them are experienced between students- school managers and teachers-school managers.

It can be said that violence between students occurs in all school types, while violence between students and teachers occurs in all school types except Multi-Program High Schools. It is stated that the violent incidents between student and school manager were experienced only in Vocational and Technical Anatolian High Schools; the violence between the teacher and the school manager was experienced in the Anatolian Imam Hatip High Schools, Anatolian High Schools and Vocational and Technical Anatolian High Schools; the violent incidents that occurred between parents and school managers were experienced in Anatolian Imam Hatip High Schools, Anatolian High Schools, Vocational and Technical Anatolian High Schools and Sports High Schools; violence between parents and teachers is experienced in Anatolian High Schools, Vocational and Technical Anatolian High Schools and Sports High Schools.

Theme 3. Findings on the Causes of Violence in the School Environment

The theme of the causes of violence in schools has been gathered under 5 sub-themes: the causes of physical violence, the causes of verbal violence, the causes of sexual violence, the causes of emotional violence, and the causes of virtual violence.

Theme 3-Sub Theme 1. Findings on Causes of Physical Violence

Findings on causes of physical violence are given in Table 6.

Table 6: Theme 3-Sub Theme 1: Causes of physical violence

\begin{tabular}{|c|c|c|}
\hline Codes & $\mathrm{f}$ & $\%$ \\
\hline Causing Related Individuals Themselves & 27 & 31.39 \\
\hline Family Related Causes & 20 & 23.26 \\
\hline Not experienced & 18 & 20.93 \\
\hline Environmental Causes & 16 & 18.61 \\
\hline School Related Causes & 5 & 5.81 \\
\hline Total & 86 & 100 \\
\hline
\end{tabular}

As seen in Table 6, it is seen that $20.93 \%$ of the school managers stated that there was no physical violence in their schools. Causes of physical violence are grouped as family related causes, environmental 
causes, causes related individuals themselves, and school related causes. It is seen that $23.26 \%$ of the causes for physical violence stated by the school managers are caused by the family, $18.61 \%$ are caused by the environment, $31.39 \%$ are caused by the individuals themselves, and $5.81 \%$ are caused by the school.

According to the views of the school managers in the Anatolian Imam Hatip High Schools the causes of physical violence are lack of affection and care in the family due to familial reasons, peer bullying, insufficient self-expression skills, wanting to prove themselves due to reasons stemming from individual themselves. According to the views of the school managers in the Anatolian High Schools the causes of physical violence are problems arising from the family and broken families due to familial reasons, friendship circle and girl-boyfriend due to environmental reasons, intolerance and non-acceptance and wanting to prove themselves due to reasons stemming from individual themselves, and lack of education due to school related reasons. Causes of physical violence in Multi-Program High School are adolescence period and lack of selfexpression skills due to reasons stemming from individual themselves. School managers stated that there is no physical violence in the Science High Schools.

According to the views of the school managers in the causes of physical violence in Vocational and Technical Anatolian High Schools are family's education level, family-related problems, broken families, financial inadequacies, lack of affection and care, life style due to familial reasons; friendship circle, girlboyfriend issue, the environment in which they live, low cultural and social levels, cultural differences, TV shows and series, social media due to environment-related reasons; peer bullying, adolescence, intolerance and inability to accept, inadequate self-expression, willingness to prove himself, lack of empathy, impatience, difficulty in anger control due to reasons stemming from individual themselves; teachers' difficulty in educating the new generation life, inadequate guidance due to school related reasons.

According to the views of the school managers in the causes of physical violence in Sports High Schools are inadequate self-expression skills, want to prove oneself, the habit of not knowing rules, behave without thinking due to reasons stemming from individual themselves; poor sanctions and lack of education due to school-related reasons.

One of the school managers of Vocational and Technical Anatolian High Schools regarding the causes of physical violence explained views as "Lack of education within the family. Since there is no training to be a parent so many families rear their children the same way like tomato-growing. Students try to solve wrong attitudes on their own, instead of informing the person concerned and solving it. They can't empathize. They are impatient (K8)". One of the Multi-Program High School managers explained the views as "Resulting from the emotional situations experienced by adolescents (K10)".

One of the school managers of the Sports High School explained views about the causes of physical violence as "Children come from primary school to high school without any obstacle in terms of discipline and pass grades. The students think that I can do whatever I want and get away with it. There are no norms and rules. Since they come with no rules, we see its reflections now more than the old years. In past, school and family ruled the child. Let's say this, habits briefly. In traditional society there is a "we" consciousness, there are rules. Today, we experienced individualism. Generations are raised in accordance with individualism. This starts with not recognizing any rules; we first stretch it and then make it a habit. When the sanction is weak, children use it and behave comfortably. We are weak in education. Nobody reads or thinks. They attack each other with the slightest word. They don't think what will happen to the end, they don't have the power. We've all been a good doctor, a good teacher, a society that knows nothing but knows much. Hence, the parent can come to the school and attack. Education is obligatory. Even if they don't know mathematics, it doesn't matter much. Let them learn to behave consciously (K16)".

One of the Anatolian High School managers stated the views as "Responsibility is too much but no authority, we have been experiencing professional burn out and tear, the prestige of institutions and teachers has decreased, the decisions taken are made from the top to the bottom, not from the bottom to up. Decisions are made without knowing the kitchen. Students know all their rights, do not know their responsibilities. We did this, "I had trouble, my child should not live these troubles" kind of thinking. A generation who thinks that they can get whatever they want. Parents are not able to take care children because of livelihood concerns. More insatiable people grow up in places that receive migration, and there is no love or respect left (K42)". 
Theme 3-Sub Theme 2. Findings on Causes of Verbal Violence

Findings on causes of verbal violence are given in Table 7.

Table 7: Theme 3-Sub Theme 2: Causes of verbal violence

\begin{tabular}{|c|c|c|}
\hline Codes & $\mathrm{f}$ & $\%$ \\
\hline Not experienced & 17 & \\
\hline No comment & 4 & \\
\hline Total & 21 & 25.30 \\
\hline Causing Related Individuals Themselves & 22 & 26.51 \\
\hline Family Related Causes & 16 & 19.28 \\
\hline Environmental Causes & 15 & 18.07 \\
\hline School Related Causes & 9 & 10.84 \\
\hline Total & 83 & 100 \\
\hline
\end{tabular}

As seen in Table 7, 25.30\% of the school managers stated that there was no verbal violence in their schools or did not give a comment about the causes of verbal violence. Causes of verbal violence are grouped as family related causes, environmental causes, causes related individuals themselves, and school related causes. It is seen that $19.28 \%$ of the reasons for verbal violence stated by the school managers are caused by the family, $18.07 \%$ are caused by the environment, $26.51 \%$ are caused by the individuals themselves, and $10.84 \%$ are caused by the school.

According to the views of the school managers in the Anatolian Imam Hatip High Schools the causes of verbal violence are experience violence due to familial reasons, reasons arise from adolescence, seeing violence as a solution due to reasons stemming from individual themselves. According to the views of the school managers in the Anatolian High Schools the causes of verbal violence are broken families, the behavioral culture that they learn, lack of love and interest due to familial reasons; girl-boyfriend issues, the environment that they live in, social media due to environmental reasons; reasons arising from adolescence, desire to be dominant, jealousy and a sense of competition due to reasons stemming from individual themselves; the counseling service that doesn't work actively, the lack of tolerance of the teachers, the lack of activities in the school due to school related reasons.

According to the views of the school managers in the Multi-Program High Schools the causes of verbal violence are social and cultural structure due to environmental reasons, the desire to be dominant, the thought that they will be exposed to less reaction than physical violence, and inadequate communication skills due to reasons stemming from individual themselves. Science High Schools' managers stated that there was no verbal violence in their schools.

Causes of verbal violence in Vocational and Technical Anatolian High School are problems arising from the family, the education level of the family, the income level of the family, broken families, slummy family, lifestyle due to familial reasons; TV programs and series, the environment in which they live, social and cultural structure, social media due to environmental reasons. In addition, other causes of verbal violence in the Vocational and Technical Anatolian High School type are the reasons arising from adolescence, the desire to be dominant, the failure to perceive their behavior as violence, habits, the effort to manifest themselves due to reasons stemming from individual themselves; the lack of education, the inactivity of the counseling service, changes in the education system, inability to provide the desired education due to school related reasons. The causes of verbal violence in the Sports High School type are insufficient communication skills, habit of not obeying rules, not behaving thoughtfully, effort to manifest oneself due to reasons stemming from individual themselves; lack of education and weak sanctions due to school-related reasons.

While one of the Multi-Program High School managers expressed views on the subject as "Thinking that the student who committed verbal violence would get less reaction compared to physical violence (K 6)". One of the 
Anatolian Imam Hatip High School managers expressed views as "Learning this in the family and thinking that behaving in this way will yield results, and that this can be a solution among peers (K 7$)^{\prime \prime}$.

One of the school managers of Vocational and Technical Anatolian High Schools said, "There are no big reasons for verbal violence. The broken family is too much. Students reflect more of their problems at school what they cannot reflect at home. The impact of social media. S/he writes on social media what s/he cannot say in daily life. And also the impact of adolescence period (K26)". One of the school managers of the Sports High School stated that "They cannot solve problems by talking (K27)".

One of the Anatolian High School managers said, "There is no environment in the school where voices don't rise. It surely happens. Guidance services need to be strong. If they do their job well, violent incidents will fall below $50 \%$. Counselor is also very important for students' deciding the field process. Teachers are lack of patience to students. Teachers have patience with their own child. Reasons are family, environment and school. If these are well coordinated, the violence will decrease, even if it does not end. Broken families are increasing day by day. The spiritual emptiness is too much in society. Social media has finished sharing. There must be social and cultural activities. There should be playgrounds. Those who are not discharged tend to be violent. There should be areas where they can relax. Class sizes became crowded. The student disregard teacher (K30)".

Theme 3-Sub Theme 3. Findings on Causes of Sexual Violence

Findings on causes of sexual violence are given in Table 8.

Table 8: Theme 3-Sub Theme 3: Causes of sexual violence

\begin{tabular}{lll}
\hline \multicolumn{1}{c}{ Codes } & $\mathrm{f}$ & $\%$ \\
\hline Not experienced & 48 & 81.36 \\
Slummy families & 2 & 3.40 \\
Family structure & 1 & 1.70 \\
Socioeconomic status & 1 & 1.70 \\
Not getting enough concern from the opposite sex & 1 & 1.70 \\
Wondering the opposite sex & 1 & 1.69 \\
The spread of obscenity & 1 & 1.69 \\
Psychological health status & 1 & 1.69 \\
The effort to show themselves & 1 & 1.69 \\
Wannabe & 1 & 1.69 \\
Coeducation & 1.69 \\
Total & 1 & 100
\end{tabular}

As seen in Table 8, 81.36\% of the school managers stated that there was no sexual violence in their schools or did not give a comment about the causes of sexual violence. The causes of sexual violence were stated by the school managers as slummy families, family structure, socioeconomic status, not getting enough concern from the opposite sex, wondering about the opposite sex and the spread of obscenity.

According to the views of the Anatolian Imam Hatip High School managers, the causes of sexual violence are slummy families, not getting enough concern from the opposite sex, and wondering about the opposite sex. The causes of sexual violence in Vocational and Technical Anatolian High School type are slummy families, family structure, socioeconomic status, spread of obscenity, psychological health status, effort to show themselves, wannabe, and coeducation. It is observed that the school managers of Anatolian High Schools, Multi-Program High Schools, Science High Schools and Sports High Schools do not explain their views on the causes of sexual violence. 
Theme 3-Sub Theme 4. Findings on Causes of Emotional Violence

Findings on causes of emotional violence are given in Table 9.

Table 9: Theme 3-Sub Theme 4: Causes of emotional violence

\begin{tabular}{|c|c|c|}
\hline Codes & $\mathrm{f}$ & $\%$ \\
\hline Not experienced & 25 & \\
\hline No comment & 6 & \\
\hline Total & 31 & 46.27 \\
\hline Causing Related Individuals Themselves & 15 & 22.39 \\
\hline Family Related Causes & 13 & 19.40 \\
\hline Environmental Causes & 7 & 10.45 \\
\hline School Related Causes & 1 & 1.49 \\
\hline Total & 67 & 100 \\
\hline
\end{tabular}

As seen in Table 9; $46.47 \%$ of the school managers stated that emotional violence did not experienced in their schools or did not give a comment on the causes of emotional violence. Causes of emotional violence are grouped as family related causes, environmental causes, causes related individuals themselves, schoolrelated causes. It is seen that $19.40 \%$ of the emotional violence reasons stated by the school managers are caused by family, $10.45 \%$ are caused by the environment, $22.39 \%$ are caused by the individuals themselves, and $1.49 \%$ are caused by the school.

According to the views of the Anatolian Imam Hatip High School managers, the causes of emotional violence are the lack of affection and care in the family due to familial reasons, and the desire to realize him/herself due to reasons stemming from individual themselves; in Anatolian High School type of school, it is seen that there are causing distress to the other people, applying pressure, competition, adolescence due to reasons stemming from individual themselves. One of the Anatolian High School managers stated causes of emotional violence as "Because they are constantly studying and racing (K53)".

In the Multi-Program High School type, it is seen that group solidarity due to environmental reasons, the effort to manifest themselves, the effort to be a group leader, the language of communication among students due to reasons stemming from individual themselves, and the managers of Science High Schools and Sports High Schools do not explain their views on the causes of emotional violence. One of the Multi-Program High School managers stated the causes of emotional violence, "It is mostly seen among our female students. An effort of self-expression and group solidarity and the need to be included in the group (K6)".

The causes of emotional violence in Vocational and Technical Anatolian High School; family-related problems, broken families, lack of love and interest, family upbringing, economic reasons due to family related reasons; TV programs and serials, environment, popular culture due to environmental reasons; insufficient communication skills, distressing the other person, applying pressure, joking, girl-boyfriend relationships, habits, a tour de force due to reasons stemming from individual themselves; changes in the education system due to school-related reasons. As a matter of fact, one of the school managers of Vocational and Technical Anatolian High School explains the causes of emotional violence as "Upbringing. Normally, if a friend has a flaw, the other person helps. But they do just the opposite (K40)".

Theme 3-Sub Theme 5. Findings on Causes of Virtual Violence

Findings on causes of virtual violence are given in Table 10. 
Table 10: Theme 3-Sub Theme 5: Causes of virtual violence

\begin{tabular}{llll}
\hline & Codes & $\mathrm{f}$ & $\%$ \\
\hline Not experienced & 25 & \\
No Comment & 5 & 45.45 \\
Total & 30 & 25.76 \\
\hline Environmental Causes & 17 & 19.70 \\
Causing Related Individuals Themselves & 13 & 9.09 \\
Family Related Causes & 6 & 100 \\
Total & 66 & \\
\hline
\end{tabular}

As seen in Table 10, $44.45 \%$ of the school managers stated that virtual violence didn't experienced in their schools or did not give a comment on the causes of virtual violence. Causes of virtual violence are grouped as family related causes, environmental causes, causes related individuals themselves. It is seen that $9.09 \%$ of the virtual violence reasons stated by the school managers are reasons caused by the family, $25.76 \%$ of them are reasons caused by environment, and $19.70 \%$ are rea sons caused by individuals themselves.

According to the views of the school managers of the Anatolian Imam Hatip High School, the causes of virtual violence are inadequate communication skills due to reasons stemming from individual themselves; in Anatolian High School, the reasons are feeling more comfortable in the virtual world due to environmental reasons, the effort to show themselves and girl-boyfriend issue due to reasons stemming from individual themselves. While one of the Anatolian Imam Hatip High School managers stated the causes of virtual violence as "being afraid of reflecting the inner world or not being able to express his/her feelings (K7)", one of the Anatolian High School managers said "Not knowing how to express themselves freely (K23)".

It is seen that the reasons for virtual violence in the Science High School type are the feeling of being more comfortable in the virtual world due to environmental reasons, and not being aware of the fact that it is violence due to reasons stemming from individual themselves. One of the Science High School managers said the reasons for the virtual violence "The students are not aware that this is violence. They said, does this concern the school? (K29)" while another Science High School manager said "They are not at a level to distinguish between rights and wrongs in an uncontrolled environment. Our students are anti-social, they feel more comfortable in these channels. Some of them question it excessively. (K18)".

In the Multi-Program High School type, it has been observed that the causes of virtual violence are the feeling of being more comfortable in the virtual world due to environmental reasons, and the student's being introverted due to reasons stemming from individuals themselves.

In Vocational and Technical Anatolian High Schools causes of virtual violence are problems arising from family, weak family authority, broken families, economic reasons due to familial reasons, TV programs and serials, widespread use of mobile phones and the internet, the prominence of the virtual environment, feeling more comfortable in the virtual World, negative examples in social media, inability to use the internet consciously, the spread of obscenity, the rapid consumption, the environment in which he lives, ina dequate communication skills due to environmental reasons, group competition, the issue of girlfriend and boyfriend, ignorance, the curiosity of learning others' privacy, joking, low level of social acceptance due o reasons stemming from individual themselves.

One of the Multi-Program High School managers stated the causes of virtual violence as "Thinking about the environment where s/he wants to live by being in the virtual world and acting with different emotions (K10)", while one of the Vocational and Technical Anatolian High School managers said, "Communication with mobile phones is very easy and widespread, obscenity is very common due to widespread use of internet. It can be very easy for young people to consume something. Internet has been becoming widespread, easier and cheaper. Not everyone should be able to reach it (K13)". Sports High School managers stated that there is no virtual violence in their schools. 


\section{RESULT AND DISCUSSION}

In this study; it is aimed to determine the views of school managers about the situation, time, place, groups and causes of violence experienced at the level of students, teachers, school managers and parents in public high schools in Bursa. According to research results we can say that violence incidents are experience d in general in the school environment in public high schools; violence incidents in the school environment occurred in the school garden, in the classroom, on corridor, in the toilet, in the canteen and also in sports areas and places where there are no cameras; violence in the school environment including the classroom can be experienced everywhere in and around the school, and it is mostly common in the school garden. Research results showed that violence events are experienced more intensely in the school environment when students are free such as during the break, after school, during the iddle class, lunch break, on school way, in the time period until the teacher came to class and that is experienced among all groups like student-student, studentteacher, parents-school managers, teachers-school managers in the school environment, but is more common among students. Likely, Opere, Kamere and Wawire (2019) found that violence occurred during meals, social events and on the way going home from school and that the main perpetrators included classmates, prefects and even teachers in their study.

The primary causes of physical, verbal and emotional violence are caused by the individuals themselves, family, environment and finally school, on the other hand, it was concluded that causes of virtual violence is perceived primarily due to environmental reasons then the individual and the family, and also school managers thought that the school had no share in virtual violence. Although the awareness of not using violence and solving problems without using violence is an awareness that develops by trainings, it is striking that school managers perceive school-related reasons to have a lower share in violence compared to others. Studies conducted support the results of this study. In the study conducted by Örki (2013) with the participation of high school students; it was concluded that factors such as media violence, negative effects of the peer group, low ties with school or problems with education, poor parent-child communication, and poor parental control have significant effects on the development of criminal and violent behavior. In the research conducted by Taşar (2019), it was concluded that "issues related to the opposite sex" were mostly shown as the cause of violence. In the study conducted by Tatlllığlu (2016) to determine the opinions of teachers, administrators and students about the sources of violence in secondary schools, it was concluded that the majority of students were affected by TV series, were affected by teachers' negative words, parents could not cooperate with the school adequately, economic problems, insufficient family communication, students' low academic success. It was concluded that the reasons for sexual violence were perceived by the school managers as indifference of families, family structure, socioeconomic status, inadequate attention from the opposite sex, curiosity about the opposite sex, and the spread of obscenity. It has been concluded that the violence experienced in schools does not differ in terms of the types of school.

Violence in the Anatolian Imam Hatip High School is experienced in the school garden and classroom environment; it can be said that it is experienced everywhere, including the internet environment in Anatolian High School, Vocational and Technical Anatolian High School and Sports High School. In a Multi-Program High School, violence is experienced in the corridor, school garden and around the school; it was concluded that violence was experienced on the internet in Science High School. It was concluded that violent incidents were experienced during the break, lunch break and after school in Anatolian Imam Hatip High School, but not experienced at school in Science High Schools. It was concluded that there is always violence in Vocational and Technical Anatolian High Schools, including the class time. All in all we can say that violence was experienced among all groups, but violence between student-student and student-teacher was more intense in all school types.

\section{SUGGESTIONS}

It is aimed to determine the views of school managers about the situation, time, place, groups and causes of violence experienced in the level of students, teachers, school managers and parents in public high schools in Bursa in this study. Based on the results of the research, the following suggestions can be presented to prevent violence in schools.

1. To work on determining goals for the future of students, especially for Vocational and Technical Anatolian High School students. 
2. To give training for students to control their physical strength and energy and to control anger.

3. To inform students, teachers, parents and administrators about emotional violence and virtual violence, to raise awareness about whether their experience is violence or not.

This research is limited to the views of school managers working in high schools in Bursa in the 20192020 academic year and violent incidents are only discussed in the context of violence in the school environment. In future studies, a study in which violence events in schools will be determined according to the views of teachers, parents and students can be designed.

\section{REFERENCES}

Arslan, Y. (2015). Okullarda yaşanan şiddet olaylarının düzey ve dinamiklerini anlamak: Batman Merkez Örneği / Türkiye. Manas Sosyal Araştırmalar Dergisi, 4(5), 1-17.

Atmaca, T. \& Öntaş, T. (2014). Velilerin öğretmenlere uyguladığı şiddete yönelik nitel bir araştırma. Anadolu Ĕ̆itim Liderliği ve Öğretim Dergisi, 2(1), 47-62.

Avc1, A. (2010). Ĕ̆itimde şiddet olgusu lise öğrencilerinde şiddet, saldırganlık ve ahlakî tutum ilişkisi, Kü̧̈ükçekmece ilçesi örneği. [Yayınlanmamış Doktora Tezi]. Marmara Üniversitesi.

Çakır, R. (2019). Lise öğrencilerinin aile ve arkadaşlarına yönelik şiddet kaynağı (Malatya Örneği). Karadeniz Uluslararası Bilimsel Dergi, 43, 185-202.

Çubukçu, Z. \& Dönmez, A. (2012). Illköğretim okul yöneticilerinin şiddet türlerine yönelik görüşleri ve şiddetle başa çıkma yöntemleri. Kuram ve Uygulamada Ĕ̆itim Yönetimi, 18 (1), 37-64.

EARGED (2008). Öğrencilerin şiddet algısı. Millî Eğitim Bakanlığı, Eğitimi Araştırma ve Geliştirme Dairesi Başkanlığı.

Erçetin, Ş.Ş. (2006). Çocuk ve suç. Hegem Yayınları

Gemici, İ. (2008). Illköğretim kurumlarında görülen şiddetin nedenleri ve önlenmesine ilişkin yönetici ve öğretmen görüşleri. [Yayınlanmamış Yüksek Lisans Tezi]. Dokuz Eylül Üniversitesi.

Hoşgörür, V. \& Orhan, A. (2017). Okulda zorbalık ve şiddetin nedenleri ve önlenmesinin yönetimi (Muğla Merkez İlçe örneği). Bayburt Eğitim Fakültesi Dergisi, 12(24), 859-880

Jasper, M. A. (1994). Issues in phenomenologyforresearchers of nursing. Journal of Advanced Nursing, 19, 309314.

Mayring, P. (2000). Qualitative content analysis [28 Paragraphs]. Forum Qualitative Sozial for schung / Forum: Qualitative Social Research, 1 (2), Art.20, http://nbn-resolving.de/urn:nbn:de:0114-fqs0002204.

Mehinezhad, V. \& Rashki, J. (2018). Causes of violence by high school students: A teachers and principals perspective. AJESI - Anadolu Journal of Educational Sciences International, 8(2), 124-148 DOI: 10.18039/ajesi.454564

Miller, S. (2003). Analysis of phenomenological data generated with children as research participants. NurseResearcher, 10(4), 68-82.

Ncontsa, V. N. \& Shumba, A. (2013). The nature, causes and effects of school violence in South African high schools. South African Journal of Education, 33(3), 1-15

Opere, O.A., Kamere, I. \& Wawire, V. (2019) School violence as a cause of non-peaceful coexistence in public secondary schools in Nairobi, Kenya. Open Journal of Social Sciences, 7(9), 130-145. https://doi.org/10.4236/jss.2019.79010

Ögel, K., Tarı, I. \& Yılmazçetin Eke, C. (2006). Okullarda suç ve şiddeti önleme. Yeniden Yayınları, No 17

Örki, H. (2013). Okullarda şiddet ve suç: Eskişehir örneği. [Yayınlanmamış Yüksek Lisans Tezi]. Anadolu Üniversitesi.

Özdere, M. \& Terzi, Ç. (2018). Liselerde öğretmene yönelik şiddetin çeşitli değişkenler açısından incelenmes i: Niğde ili örneği. Ĕ̆itim Kuram ve Uygulama Araştırmaları Dergisi, 4(1), 68-88. 
Özgür, G., Yörükoğlu, G. \& Baysan Arabacı, L. (2011). Lise öğrencilerinin şiddet algıları, şiddet eğilim düzeyleri ve etkileyen faktörler. Psikiyatri Hemşireliği Dergisi - Journal of Psychiatric Nursing, 2(2), 53-60.

Sayın, N. (2008). Ortaöğretim kurumlarında kriz yönetimi stratejisinin incelenmesi. [Yayınlanmamış Doktora Tezi]. Marmara Üniversitesi.

Sezgin, F. ve Özok, D. (2006, Mart). Okulda şiddet olgusunun W. Glasser'in seçim kuramına göre açıklanması. 1. Şiddet ve okul: Okul ve çevresinde çocuğa yönelik şiddet ve alınabilecek tedbirler - Uluslararası Katılımlı Sempozyumu Bildiri Kitabı (s. 220-235)içinde. MEB - UNICEF.

Şener, G. (2019). Orta eğitim kademesindeki öğretmen ve öğrencilerin şiddet algılarının kırsaldaki görünürlüğü. Kuramsal Eğitimbilim Dergisi, 12(3), 1124-1141.

Taşar, H. H. (2019). Eğitimde şiddet ve şiddeti azaltma. Erciyes İletişim Dergisi, 6(2), 899-912. DOI: 10.17680/erciyesiletisim.557870 .

Tatlılığlu, K. (2016). Okullarda şiddet ve zorbalık: Risk faktörleri, koruma, önleme ve müdahale hizmetleri: Konya örneği. Bingöl Üniversitesi Sosyal Bilimler Enstitüsü Dergisi, 6(6), 12, 209-231.

Ünlü, A., Evcin, U., Burakgazi Yılmaz, H., \& Dalkılıç, A. (2013). İstanbul devlet liselerinde suç ve şiddet yaygınlığı: Okul türlerinin karşılaştırılması. AnatolianJournal of Psychiatry, 14, 152-60.

Von Reininghaus, G.N., Castro, P.J. \& Frisancho, S. (2013). School violence: Subjective theories of academic advisory board members from six Chilean schools. Interdisciplinaria, 30(2), 219-234

Yıldırım, A. \& Şimşek, H. (2008). Sosyal bilimlerde nitel araştırma yöntemleri (6. Baskı). Seçkin Yayıncılık.

Yüzer, M. F. (2013). Okullarda şiddetin önlenmesinde güvenlik hizmetlerinin rolü: Okul polisi uygulaması Ankara ili örneği. [Yayınlanmamış Yüksek Lisans Tezi]. Polis Akademisi.

2023 Vizyon Belgesi http://2023vizyonu.meb.gov.tr/ adresinden 2 Şubat 2021 tarihinde alınmıştır.

Eğitim Ortamlarında Şiddetin Önlenmesi ve Azaltılması 18.10.1995 tarih ve 2701 sayılı 1995/81 No'lu Genelgehttps://orgm.meb.gov.tr/meb_iys_dosyalar/2015_10/08113955_eitimortamlarndaiddetinnlenmes iveazaltlmasgenelgesi.pdf adresinden 2 Şubat 2021 tarihinde alınmıştır. 